\title{
The ketogenic diet corrects metabolic hypogonadism and preserves pancreatic ß-cell function in overweight/obese men: a single-arm uncontrolled study
}

\author{
Sandro La Vignera ${ }^{1} \cdot$ Rossella Cannarella $\mathbb{1}^{1} \cdot$ Fabio Galvano $^{2} \cdot$ Agata Grillo $^{3}$. Antonio Aversa ${ }^{4} \cdot$ Laura Cimino $^{1}$. \\ Cristina M. Magagnini ${ }^{1} \cdot$ Laura M. Mongioi $^{1} \cdot$ Rosita A. Condorelli ${ }^{1} \cdot$ Aldo E. Calogero $^{1}$
}

Received: 23 June 2020 / Accepted: 2 October 2020 / Published online: 15 October 2020

(c) The Author(s) 2020

\begin{abstract}
Background Overweight and obesity are increasingly spread in our society. Low testosterone levels are often present in these patients, the so-called metabolic hypogonadism, that further alters the metabolic balance in a sort of vicious cycle. Very low-calorie ketogenic diet (VLCKD) has been reported to efficiently reduce body weight, glycaemia, and the serum levels of insulin, glycated hemoglobin, but its effects on $\beta$-cell function and total testosterone (TT) levels are less clear. Aim To evaluate the effects of VLCKD on markers suggested to be predictive of $\beta$-cell dysfunction development, such as proinsulin or proinsulin/insulin ratio, and on TT values in a cohort of overweight or obese nondiabetic male patients with metabolic hypogonadism.

Methods Patients with overweight or obesity and metabolic hypogonadism underwent to VLCKD for 12 weeks. Anthropometric parameters, blood testing for the measurement of glycaemia, insulin, C-peptide, proinsulin, TT, calculation of body-mass index (BMI), and HOMA index were performed before VLCKD and after 12 weeks.

Results Twenty patients (mean age 49.3 \pm 5.2 years) were enrolled. At enrollement all patients presented increased insulin, HOMA index, C-peptide, and proinsulin levels, whereas the proinsulin/insulin ratio was within the normal values. After VLCKD treatment, body weight and BMI significantly decreased, and $14.9 \pm 3.9 \%$ loss of the initial body weight was achieved. Glycaemia, insulin, HOMA index, C-peptide, and proinsulin significantly decreased compared to pre-VLCKD levels. Serum glycaemia, insulin, C-peptide, and proinsulin levels returned within the normal range in all patients. No difference in the proinsulin/insulin ratio was observed after VLCKD treatment. A mean increase of $218.1 \pm 53.9 \%$ in serum TT levels was achieved and none of the patients showed TT values falling in the hypogonadal range at the end of the VLCKD treatment.

Conclusions This is the first study that evaluated the effects of VLCKD on proinsulin, proinsulin/insulin ratio, and TT levels. VLCKD could be safely used to improve $\beta$-cell secretory function and insulin-sensitivity, and to rescue overweight and obese patients from $\beta$-cell failure and metabolic hypogonadism.
\end{abstract}

Keywords VLCKD $\cdot$ Proinsulin · Insulin • $\beta$-cell dysfunction $\cdot$ Metabolic hypogonadism $\cdot$ Testosterone

Rosita A. Condorelli

rosita.condorelli@unict.it

1 Department of Clinical and Experimental Medicine, University of Catania, Catania, Italy

2 Department of Biomedical and Biotechnological Sciences, University of Catania, Catania, Italy

3 Labogen (Specialized Human Genetics Laboratory), Catania, Italy

4 Department of Experimental and Clinical Medicine, University Magna Graecia of Catanzaro, Catanzaro, Italy

\section{Introduction}

Overweight and obesity are characterized by an excess of fat-mass accumulation. They represent two widely spread conditions, whose prevalence doubled since the 1980s, currently affecting one-third of the global population [1]. There is a tight connection between obesity and the development of comorbidities such as type 2 diabetes mellitus (T2DM), dyslipidemia, cerebrovascular and cardiovascular disease, arthrosis, psychiatric disorders, obstructive sleep apnea, cholelithiasis, and non-alcoholic fatty liver disease. 
Thus, it heavily affects the quality of life and severely burdens the healthcare.

In the recent decade, male hypogonadism has been fully recognized as a complication of overweight and obesity, and the term "metabolic hypogonadism" has been coined. Particularly, the reduction of sex hormone-binding globulin (SHBG) serum levels, the increased androgen aromatization into estrogens, and the pro-inflammatory cytokine-dependent attenuation of luteinizing hormone (LH) pulses [2] represent some of the mechanisms explaining the occurrence of male hypogonadism in overweight and obesity [3]. Vice versa, low testosterone levels can promote adipocyte proliferation [4] and influence the pancreatic $\beta$-cell function [5]. Consequently, hypogonadism can worsen obesity and favor the development of metabolic diseases in overweight and obese patients, creating a sort of vicious circle.

Several therapeutic approaches have been developed to face up overweight and obesity, such as diet or weight-loss medications, although with documented poor efficacy, side effects, and restricted indications [6]. Bariatric surgery seems to have positive results in severely obese patients with or without comorbidity [7] and appears to reverse both hypogonadism [8] and metabolic abnormalities [9].

Ketogenic diets (KDs) are high-fat, normal-protein, and low-carbohydrate diet protocols firstly introduced in the 1920s for the treatment of refractory epilepsy, due to the benefits of ketone bodies (D-3- $\beta$-hydroxybutyrate, acetoacetate, and acetone) on epileptic seizures [10]. The principle of $\mathrm{KD}$ is a marked restriction of carbohydrate intake that pushes the energy supply from the $\beta$-oxidation of fatty acids, thus synthesizing acetyl-CoA. In the case of low glucose availability, acetyl-CoA escapes from the tricarboxylic acid cycle and contribute, by condensation, to the formation of ketone bodies [11]. The marked lipolysis that occurs in KD led to the idea that these protocols could be used for fat loss. Therefore, the "Atkins" diet and other similar low-calorie and low-carbohydrate KDs were subsequently developed with enough protein content for the maintenance of lean body mass and thus obtain rapid weight loss with lean mass savings [12-16]. These programs, which form the basis of VLCKD, are safe and have proven to have beneficial effects on blood pressure, glycaemia, and lipid profile [17]. Currently, VLCKD is defined by a document of the Italian Society of Endocrinology as a dietary protocol characterized by a marked restriction of daily carbohydrate intake ( $<30 \mathrm{~g}$ /day, approximately corresponding to $\sim 13 \%$ of the daily energy intake), a $1.2-1.5 \mathrm{~g} / \mathrm{Kg}$ protein intake $(\sim 43 \%)$ (which is not a high-protein content) and vegetablederived (mainly unsaturated) fat intake ( 44\%), providing an overall total energy intake lower than $800 \mathrm{kcal}$ [11].

Although VLCKD has been reported to efficiently reduce body weight, the levels of glycaemia, insulin, and glycated hemoglobin $(\mathrm{HbAlc})$ in patients with overweight or obesity
$[18,19]$, its effects on $\beta$-cell function are less clear. Also, despite VLCKD has been suggested for the treatment of metabolic hypogonadism [11], according to the authors' knowledge, no study documented the effect of this diet protocol on total testosterone (TT) serum levels, so far. Therefore, this study aimed to evaluate the effects of VLCKD on $\beta$-cell markers suggested as predictive of $\beta$-cell dysfunction development (e.g., proinsulin or proinsulin/ insulin ratio [20-23]) and on TT values in a cohort of overweight or obese nondiabetic male patients with metabolic hypogonadism.

\section{Subject and methods}

\section{Ethical aspects}

The experimental protocol was designed to be an observational prospective study. It was performed in the Division of Andrology and Endocrinology of the Teaching hospital "G. Rodolico", University of Catania, Catania, Italy. The internal Institutional Review Board approved the study protocol. An exhaustive explanation of the study purpose was given to each participant and informed written consent was obtained in compliance with Helsinki's declaration.

\section{Patient selection}

Male patients with overweight or obesity, older than 18 years, consulting our Division for weight loss, underwent comprehensive medical history collection, physical examination, and laboratory testing. Patients with signs or symptoms suggestive of $\mathrm{T}$ deficiency underwent to TT measurement. Those with hypogonadism (TT $<264 \mathrm{ng} / \mathrm{dl}$ confirmed by at least two measurements of serum TT [22]) willing to undergo to VLCKD were recruited in this study.

The exclusion criteria were given by the presence of the following [8]: type 1 diabetes mellitus, latent autoimmune diabetes, T2DM, chronic renal failure with estimated glomerular filtration rate $<60 \mathrm{ml} / \mathrm{min} / 1.73 \mathrm{~m}^{2}$, active or severe infections, recent major cardiovascular event, unstable angina, cardiac arrhythmias, frailty, $48 \mathrm{~h}$ prior surgery or invasive procedures, eating disorders and other psychiatric disturbances. Also, patients with hypertension, dyslipidemia, and users of drugs for the treatment of chronic diseases in the 3 months before enrollment were excluded. Finally, patients with hypogonadism due pituitary or testicular diseases were excluded.

\section{Diet protocol}

VLCKD protocol was based on marked restriction of daily carbohydrate intake ( $<30 \mathrm{~g} /$ day), a fat intake of $\sim 44 \%$, and 
$\sim 43 \%$ was the intake of proteins. Particularly, $1.4-1.5 \mathrm{~g} / \mathrm{Kg} /$ daily protein of the ideal body weight was chosen for the patients enrolled in this study. The protocol consisted of five main phases. The first (VLCKD: $600-800 \mathrm{kcal} / \mathrm{day}$ ) was based on a total replacement of natural proteins with five substitutive meals (breakfast, lunch, dinner, and two snacks, one mid-morning and one mid-afternoon). Vegetables with low glycemic index were allowed during lunch and dinner. Two different programs could be chosen in the second phase (low-calorie ketogenic diet: $800-1000 \mathrm{kcal} /$ day). The first was replacement of a single protein preparation with a natural protein food (lunch or dinner), such as meat, eggs, and fish; the second option was keeping breakfast and snacks with protein preparations and replace both lunch and dinner with natural proteins. Only vegetables with a low glycemic index were allowed in both phases. These two phases had a 12-week-long duration during which ketosis was maintained. Micronutrients, consisting of vitamins (complex B, C, and E), minerals (sodium, potassium, magnesium, and calcium) and omega-3 fatty acids, were supplemented. The third phase (low-calorie diet: $1200-1500 \mathrm{kcal} /$ day) was characterized by gradual carbohydrate replenishment, based on their glycemic index. Protein preparations were also progressively replaced with natural foods and vegetables with a higher glycemic index were reintroduced. Protein preparations were used for breakfast and one snack, while the other snack was replaced by fruit. Meat, eggs, fish, and dairy products were introduced 3-4 times a week for lunch and dinner. In this phase, at least $10 \mathrm{~min}$ of physical activity per day were suggested. Pasta or bread (lunch) and cereals (breakfast or dinner) and, finally, legumes (lunch or dinner) were reinstated in the fourth and fifth phases (total daily calorie intake between 1500 and $2000 \mathrm{kcal} / \mathrm{day}$, depending on the individual). $150 \mathrm{~min} /$ week of physical activity was recommended in these phases to achieve body weight control. In the present study, each patient underwent to the diet protocol for at least 12 weeks (which included the 1st and the 2 nd phases). All patients voluntarily referred to Therascience Lignaform (Monaco, France), for the purchase of substitutive meals.

\section{Anthropometric parameters and hormonal measurements}

Anthropometric and biochemical parameters were evaluated at enrollment and at the end of the second phase (after 12 weeks from the beginning of VLCKD). Beta-hydroxybutyrate levels were detected weekly through a reflex metrics detection system and kept between 0.5 and $0.7 \mathrm{mmol} / \mathrm{l}$.

Body weight was measured in fasting conditions, using the same calibrated scale, without shoes, and with an empty bladder. Each man underwent to blood testing for the measurement of glycaemia, insulin, C-peptide, proinsulin, and TT. The blood samples were collected in the morning (8-10 a.m.), in a fasting state. Laboratory evaluation was performed by electrochemioluminescence (ECLIA) (Roche Cobas, Germany) for plasma glucose, insulin C-peptide and TT. Serum proinsulin was determined by immunosorbent assay (Mercovia, Biomerieux, France).

The reference values were as follows: glycaemia $60-100 \mathrm{mg} / \mathrm{dl}$ [intra-assay coefficient of variation (CV) $1.7 \%$; inter-assay CV: $1.2 \%$ ], insulin $<25 \mu \mathrm{IU} / \mathrm{ml}$ (intra-assay CV 1.7\%; inter-assay CV: $1.2 \%$ ), C-peptide $0.8-4 \mathrm{ng} / \mathrm{ml}$ (intra-assay $\mathrm{CV} 2.1 \%$; inter-assay $\mathrm{CV}: 1.6 \%$ ), proinsulin $<11 \mathrm{pmol} / \mathrm{l}$ (intra-assay CV: $4.8 \%$; inter-assay CV: $5.9 \%$ ), TT 300-1000 ng/dL (intra-assay CV 4.6\%; inter-assay CV: 2.1\%). The homeostasis model assessment (HOMA) index was evaluated using the formula: [glycaemia $(\mathrm{mg} / \mathrm{dl}) \times$ insulin $(\mu \mathrm{IU} / \mathrm{ml})] / 405$, and those values falling into the 0.23-2.5 range were considered as normal. The proinsulin/ insulin ratio was calculated using the formula: proinsulin $(\mathrm{pmol} / \mathrm{l}) /[$ insulin $(\mu \mathrm{IU} / \mathrm{ml}) \times 7.175]$, where 7.175 is the conversion factor for $\mu \mathrm{IU} / \mathrm{ml}$ to $\mathrm{pmol} / \mathrm{l}$, as shown elsewhere [24].

\section{Statistical analysis}

Results are reported as mean \pm SD for continuous variables throughout the study. Normality was evaluated using the Shapiro-Wilk test and all variables resulted normally distributed. Analysis of data was hence performed by the Student $t$ test. Statistical analysis was performed using SPSS 22.0 for Windows (SPSS Inc., Chicago, IL, USA). A $p$ value of $<0.05$ was accepted as statistically significant. A trend was assumed for $p$ values ranging from 0.05 to 0.099 .

\section{Results}

Applying the above-mentioned exclusion criteria, 38 patients were initially considered for inclusion. Eighteen patients were excluded for low compliance to the VLCKD protocol $(n=8)$ and recurrent fever $(n=2)$. Eight patients quitted for economic reasons. Therefore, 20 patients (mean age $49.3 \pm$ 5.2 years) were ultimately enrolled in this study. All patients completed the VLCKD protocol and no drops out were registered. At enrollment, the mean weight and BMI were $93.0 \pm 6.5 \mathrm{Kg}$ and $32.0 \pm 3.1 \mathrm{Kg} / \mathrm{m} 2$, respectively. Proinsulin/ insulin ratio $(0.04 \pm 0.01)$ was lower than the values suggested to predict B-cell exhaustion [21, 22]. Also, the mean fasting glycaemia $(93.6 \pm 13.5 \mathrm{mg} / \mathrm{dl})$ was within the normal range, and $40 \%$ of patients had impaired fasting glucose $(\geq 100 \mathrm{mg} / \mathrm{dl})$. By contrast, the entire cohort showed elevated insulin levels $(40.4 \pm 7.1 \mu \mathrm{IU} / \mathrm{ml})$, HOMA index $(9.3 \pm 2.2)$, and C-peptide levels $(5.2 \pm 1.1 \mathrm{ng} / \mathrm{ml})$, indicating the presence of insulin-resistance, and elevated serum proinsulin levels $(12.6 \pm 1.1 \mathrm{pmol} / \mathrm{l})$, suggesting $\beta$-cell dysfunction. 

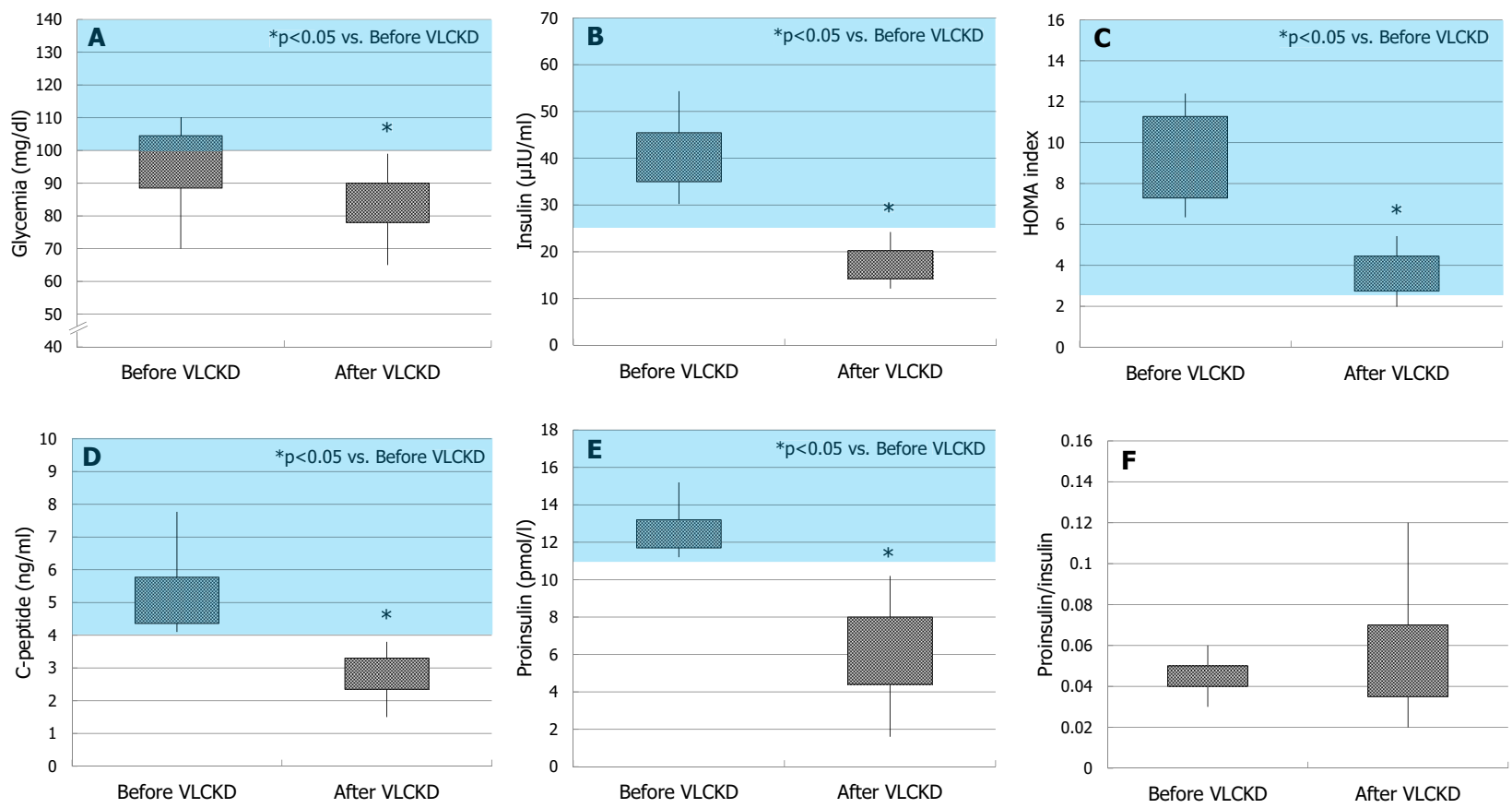

Fig. 1 Metabolic parameters before and after very low-calorie ketogenic diet (VLCKD). The pink rectangles indicate the range of values considered abnormal $(\geq 100 \mathrm{mg} / \mathrm{dl}$ for glycaemia, $\geq 25 \mu \mathrm{IU} / \mathrm{ml}$ for insulin, $\geq 2.5$ for HOMA index, $\geq 4 \mathrm{ng} / \mathrm{ml}$ for C-peptide, and $\geq 11 \mathrm{pmol} / \mathrm{l}$ for proinsulin). At enrollment, values of insulin (b), HOMA index (c), C-peptide (d), and proinsulin (e) were outside the normal range in all

patients. With the exception for proinsulin/insulin ratio (f), all values decreased significantly after VLCKD compared to their respective values at enrollment (a-e). The end of diet glycaemia (a), insulin (b), C-peptide (d), and proinsulin (e) levels returned within the normal range in all patients

Serum TT levels $(177.7 \pm 36.5 \mathrm{ng} / \mathrm{dl})$ showed the presence of hypogonadism in all patients, as for the inclusion criterion. Mean serum LH levels were $2.6 \pm 0.6 \mathrm{IU} / \mathrm{l}$.

A significant decrease of body weight $(79.1 \pm 5.8 \mathrm{Kg})$ and BMI $(27.2 \pm 2.8 \mathrm{Kg} / \mathrm{m} 2)(p<0.01)$ was observed after VLCKD treatment. The patients overall lost $14.9 \pm 3.9 \%$ of the initial body weight. Glycaemia $(83.5 \pm 10.6 \mathrm{mg} / \mathrm{dl})$, insulin $(17.6 \pm 3.8 \mu \mathrm{IU} / \mathrm{ml})$, HOMA index $(3.7 \pm 1.0)$, Cpeptide $(2.8 \pm 0.7 \mathrm{ng} / \mathrm{ml})$, and proinsulin $(6.2 \pm 2.5 \mathrm{pmol} / \mathrm{l})$ significantly decreased $(p \leq 0.01)$ compared to pre-VLCKD levels. Notably, serum glycaemia, insulin, C-peptide, and proinsulin levels returned within the normal range in all patients. No difference in proinsulin/insulin ratio was observed $(0.05 \pm 0.03, p>0.1)$ after VLCKD (Fig. 1). TT significantly increased $(371.2 \pm 43.7 \mathrm{ng} / \mathrm{dl}, p<0.01)$ and none of the patients showed TT values falling in the hypogonadal range following VLCKD; Overall, TT levels increased by the $218.1 \pm 53.9 \%$. Thus, VLCKD rescued from metabolic hypogonadism (Fig. 2).

\section{Discussion}

The present study was conducted to evaluate the effects of VLCKD on pancreatic B-cell function and TT levels in a cohort of overweight/obese nondiabetic male patients with

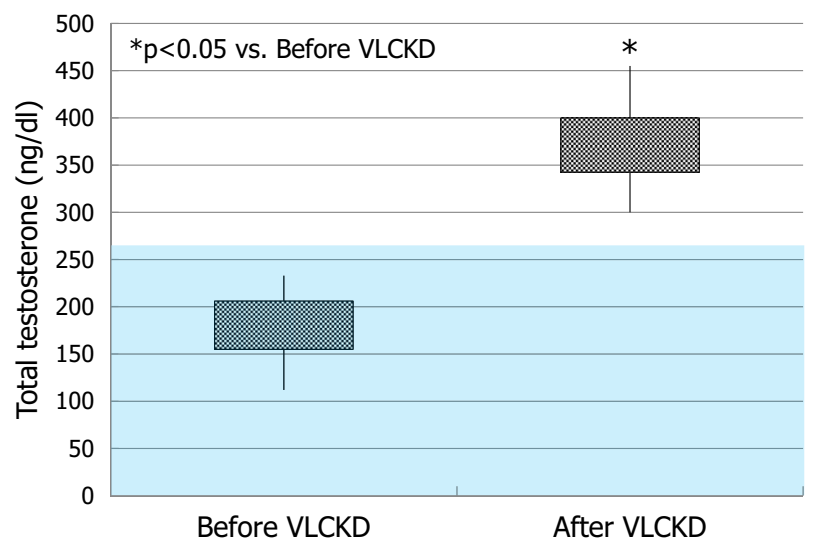

Fig. 2 Baseline and end of diet total testosterone (TT) levels. TT values increased significantly after very low-calorie ketogenic diet (VLCKD). The pink rectangle indicates values lower than $264 \mathrm{ng} / \mathrm{dl}$, cutoff for the diagnosis of hypogonadism according to the last Endocrine Society guidelines (Bhasin et al., 2018). At enrollment, all patients had metabolic hypogonadism. None of the patients showed end of diet TT values falling within the hypogonadal range

metabolic hypogonadism. The diagnosis of hypogonadism was made according to the latest guidelines of the Endocrine Society [25].

Overweight and obese subject lead the $\beta$ cells of the pancreas to a secretory effort, as they are called to release a greater amount of insulin to maintain glucose levels within 
the physiological range. Accordingly, hyperinsulinemia is present in the vast majority of obese patients [26]. Overweight/obesity causes the development of insulin-resistance in peripheral tissues, which, in turn, increases even more the release of insulin. The secretory effort of the $\beta$-cells is responsible for the onset of a progressive functional failure that ultimately results in T2DM. Markers of $\beta$-cell dysfunction have been proposed as more reliable predictors of T2DM development in the Caucasian population than markers of insulin-resistance [27].

Proinsulin, an insulin precursor with glucose-lowering effects, is one of the proposed markers. Ancient double-blind phase II studies aimed at assessing the possible therapeutic role of proinsulin were prematurely interrupted due to the occurrence of macrovascular events in the proinsulin arm, in newly diagnosed patients with DM [28]. This supported the contention that proinsulin has adverse effects. Indeed, similarly to insulin, it can trigger the MAP-kinase pathway, leading to macrovascular disease [28]. Thus, the positive correlation between proinsulin and premature coronary artery disease has already been established [29-31]. Proinsulin is released by pancreatic $\beta$-cells in an increasing manner when they reach a late stage of deterioration $[32,33]$, as a further glucose-lowering tentative to delay the onset of T2DM. Large population studies with a duration of up to 27 years reported increased serum proinsulin levels as predictors of T2DM development within 2-7 years [27, 34-36]. More recently, the cutoff value of proinsulin $\geq 7.829 \mathrm{pmol} / 1$ has been reported to be a predictor of $\beta$-cell dysfunction with a sensitivity of $95.8 \%$ and a specificity of $72.2 \%$ in a cohort of obese adolescents [22].

A disproportionate secretion of proinsulin has been described in patients with T2DM2 and it has been implied as a strong predictor of $\beta$-cell dysfunction and insulinresistance [37]. Some authors have attempted to find a cutoff value of the proinsulin/insulin ratio. In a case-control study on 50 patients with T2DM and diabetic nephropathy, the value of 0.1145 has been suggested to predict insulinresistance with relatively high sensitivity (92.3\%) but with low specificity (60.2\%) [23]. Similarly, the value of 0.1545 has been reported as predictive of insulin-resistance with lower sensitivity $(87.5 \%)$ but similar specificity $(61.1 \%)$ in adolescents with obesity [22].

No study has investigated the effects of VLCKD on proinsulin and proinsulin/insulin ratio so far. All the patients enrolled in the present study showed high proinsulin levels, which could reveal the presence of $\beta$-cell dysfunction and a predisposition to T2DM development later on. After the VLCKD treatment, proinsulin mean value was lower than $7.829 \mathrm{pmol} / \mathrm{l}$ suggesting a rescue of $\beta$-cell dysfunction [22], and this also decreased the risk for the patients to develop proinsulin-induced macrovascular complications [28]. Pre-VLCKD proinsulin/insulin ratio in all patients felt within the normal range according to the available literature [22, 23]. This may explain why the proinsulin/insulin ratio did not change significantly at the end of the diet.

The effects of VLCKD on body-weight, glycaemia, insulin, and C-peptide, have been more widely investigated. A meta-analysis carried out on 1577 patients with obesity randomized in the low-fat diet $(n=787)$ and VLCKD $(n=790)$ (females were the majority in almost all the studies included in the meta-analysis) has shown significant decrease in body-weight and blood-pressure in subjects assigned to VLCKD than low-fat diet, but no significant difference was found for glucose, insulin, and $\mathrm{HbAlc}$ levels [18]. However, a subsequent meta-analysis on 801 adult patients with overweight or obesity treated with VLCKD and kept in ketosis for at least 4 weeks showed a significant amelioration of body-weight, lipid profile, $\mathrm{HbAlc}$, blood pressure, and liver function [19]. The lowering effects of VLCKD on blood glucose, insulin, and HbA1c have been confirmed by several studies [38-41]. Benefits on insulinresistance (measured by the HOMA index) and insulinsensitivity (measured by HOMA $\beta$ or the WBISI index) have also been reported [42-44] and are consistent with the results of the present study. In fact, we even found a normalization of glycaemia, insulin, C-peptide, and a significant decrease of the HOMA index, which is in line with previous studies that reported T2DM remission [38-41].

Our study was carried out in patients with hypogonadism. Low testosterone levels worsen peripheral insulinresistance and therefore push toward the development of T2DM [45]. More in detail, testosterone can influence carbohydrate, protein, and lipid metabolism. Based on the hypogonadal-obesity-adipocytokine hypothesis, central obesity associates with lower testosterone levels due to the aromatization into estrogen occurring in adipocytes. In turn, the activity of lipoprotein lipase, involved in the storage of triglycerides into the adipocytes, and the differentiation of pluripotent stem cells into mature adipocytes are favored by the low testosterone levels [46]. The subsequent adipocyte accumulation and enlargement leads to insulin-resistance. Furthermore, pro-inflammatory cytokines released by adipocytes (e.g., TNF $\alpha$, IL6) and the increase of circulating leptin and estrogens are all involved in the inhibition of kisspeptin neurons. This results in a decreased $\mathrm{GnRH}$ secretion and lower LH pulses and, therefore, in low LHstimulated testosterone secretion. Also, leptin directly inhibits testosterone release from the Leydig cells [46]. These mechanisms underlie the pathogenesis of metabolic hypogonadism, occurring in up to half of the obese patients [47]. Thus, hypogonadism represents an additional risk factor in overweight and obese patients for the development of metabolic and cardiovascular complications [48]. Hence, restoration of testosterone levels is of great importance in 
patients with overweight or obesity to decrease the risk of developing long-term sequels.

A randomized controlled trial assessed the effects of a 10-week-long very-low-energy diet (VLED) protocol (without ketosis) on testosterone levels, describing a 30\% increase compared to the values before diet [49]. This finding has also been confirmed elsewhere [50]. Another randomized placebo-controlled trial investigated the role of testosterone replacement therapy on body composition in 100 obese male patients on VLED. The authors concluded that the testosterone plus VLED arm of the study was associated with fat-mass loss, while the placebo plus VLED arm showed both fat- and lean-mass losses [51]. This highlights the importance of normal testosterone levels in the effects of diet on body composition. In the present study, we report the effects of VLCKD on TT levels. Metabolic hypogonadism is a functional and potentially reversible condition, which can benefit from diet, bariatric surgery, and even drugs such as selective estrogen receptor modulators (SERM) [8, 52-54]. At the best of our knowledge, this is the first study showing the effects of VLCKD on metabolic hypogonadism. Patients on VLCKD obtained a $200 \%$ increase of serum TT levels and a complete remission from metabolic hypogonadism since none of the enrolled patients showed TT levels falling within the hypogonadal range after VLCKD. However, these results warrant confirmation in controlled double-arm studies to evaluate the effectiveness of VLCKD compared to VLCD.

Our results need to be taken with care. The small sample size and the absence of a control group represents limits of the present study and further double-blinded randomized controlled trials are warranted to confirm our findings. In addition, in the present study hypogonadism was defined for $\mathrm{TT}<264 \mathrm{ng} / \mathrm{dl}$, as the Endocrine Society guidelines recommend [25]. Neither measurement of SHBG and albumin, nor free-T calculation was available in patients with TT in "grey zone“" (264-300 ng/dl), which may have possibly impacted on the real prevalence of hypogonadism in the enrolled patients.

In conclusion, the present study explored the effects of VLCKD on body weight, indices of $\beta$-cell dysfunction, insulin-resistance, and on serum TT levels in overweight or obese male patients with metabolic hypogonadism. According to the available literature, we found that VLCKD was effective on body-weight and insulin-resistance. This was the first study to report the normalization of proinsulin and TT levels after 12 weeks of VLCKD-induced ketosis. This suggests the safety of ketonemia for $\beta$-cells and the effectiveness of VLCKD in restoring $\beta$-cell dysfunction and the gonadal function. Thus, VLCKD could be used to improve $\beta$-cell secretory function and insulin-sensitivity, and to rescue $\beta$-cells from exhaustion and metabolic hypogonadism.
Acknowledgements This study was supported in part by a grant from the Ministry of Education, University and Research (PRIN 2017XLFJAX), Rome, Italy. Open access funding provided by Università degli Studi di Catania within the CRUI-CARE Agreement.

Funding This research did not receive any specific grant from funding agencies in the public, commercial, or not-for-profit sectors.

\section{Compliance with ethical standards}

Conflict of interest The authors declare that there is no conflict of interest that could be perceived as prejudicing the impartiality of the research reported.

Publisher's note Springer Nature remains neutral with regard to jurisdictional claims in published maps and institutional affiliations.

Open Access This article is licensed under a Creative Commons Attribution 4.0 International License, which permits use, sharing, adaptation, distribution and reproduction in any medium or format, as long as you give appropriate credit to the original author(s) and the source, provide a link to the Creative Commons license, and indicate if changes were made. The images or other third party material in this article are included in the article's Creative Commons license, unless indicated otherwise in a credit line to the material. If material is not included in the article's Creative Commons license and your intended use is not permitted by statutory regulation or exceeds the permitted use, you will need to obtain permission directly from the copyright holder. To view a copy of this license, visit http://creativecommons. org/licenses/by/4.0/.

\section{References}

1. Y.C. Chooi, C. Ding, F. Magkos, The epidemiology of obesity. Metabolism 92, 6-10 (2019). https://doi.org/10.1016/j.metabol. 2018.09.005

2. E. Sarchielli, P. Comeglio, R. Squecco et al. Tumor Necrosis Factor- $\alpha$ Impairs Kisspeptin Signaling in Human GonadotropinReleasing Hormone Primary Neurons. J. Clin. Endocrinol. Metab. 102(1), 46-56 (2017). https://doi.org/10.1210/jc.2016-2115

3. M. Grossmann, Hypogonadism and male obesity: focus on unresolved questions. Clin. Endocrinol. (Oxf.) 89(1), 11-21 (2018). https://doi.org/10.1111/cen.13723

4. A. Barbosa-Desongles, C. Hernández, R. Simó, D.M. Selva, Testosterone induces cell proliferation and cell cycle gene overexpression in human visceral preadipocytes. Am. J. Physiol. Cell Physiol. 305(3), C355-C359 (2013). https://doi.org/10.1152/a jpcell.00019.2013

5. W. Xu, J. Morford, F. Mauvais-Jarvis, Emerging role of testosterone in pancreatic $\beta$-cell function and insulin secretion. J. Endocrinol. 2019 Jan. pii: JOE-18-0573.R1. https://doi.org/10.1530/JOE-180573

6. D.K. Patel, F.C. Stanford, Safety and tolerability of newgeneration anti-obesity medications: a narrative review. Postgrad. Med. 130(2), 173-182 (2018). https://doi.org/10.1080/ 00325481.2018 .1435129

7. D.E. Arterburn, D.A. Telem, R.F. Kushner, A.P. Courcoulas, Benefits and risks of bariatric surgery in adults: a review. JAMA 324(9), 879-887 (2020). https://doi.org/10.1001/jama.2020.12567

8. G. Corona, G. Rastrelli, M. Monami et al. Body weight loss reverts obesity-associated hypogonadotropic hypogonadism: a 
systematic review and meta-analysis. Eur. J. Endocrinol. 168(6), 829-843 (2013). https://doi.org/10.1530/EJE-12-0955

9. N.B. Jørgensen, S.H. Jacobsen, C. Dirksen et al. Acute and longterm effects of Roux-en-Y gastric bypass on glucose metabolism in subjects with Type 2 diabetes and normal glucose tolerance. Am. J. Physiol. Endocrinol. Metab. 303(1), E122-E131 (2012). https://doi.org/10.1152/ajpendo.00073.2012

10. R.M. Wilder, The effects of ketonemia on the course of epilepsy. Mayo. Clin. Proc. 2, 307-308 (1921)

11. M. Caprio, M. Infante, E. Moriconi, A. Armani, A. Fabbri, G. Mantovani, S. Mariani, C. Lubrano, E. Poggiogalle, S. Migliaccio, L.M. Donini, S. Basciani, A. Cignarelli, E. Conte, G. Ceccarini, F. Bogazzi, L. Cimino, R.A. Condorelli, S. La Vignera, A.E. Calogero, A. Gambineri, L. Vignozzi, F. Prodam, G. Aimaretti, G. Linsalata, S. Buralli, F. Monzani, A. Aversa, R. Vettor, F. Santini, P. Vitti, L. Gnessi, U. Pagotto, F. Giorgino, A. Colao, A. Lenzi, Cardiovascular Endocrinology Club of the Italian Society of Endocrinology. Very-low-calorie ketogenic diet (VLCKD) in the management of metabolic diseases: systematic review and consensus statement from the Italian Society of Endocrinology (SIE). J. Endocrinol. Investig. 42(11), 1365-1386 (2019). https://doi.org/ 10.1007/s40618-019-01061-2

12. G.L. Blackburn, J.P. Flatt, G.H. Clowes, T.F. O' Donnell, T.E. Hensle, Protein sparing therapy during periods of starvation with sepsis of trauma. Ann. Surg. 177(5), 588-597 (1973)

13. R. Nagy, Dr. Atkins' diet revolution: a review. Va Med. Mon. 101 (5), 383-385 (1974)

14. B.R. Bistrian, G.L. Blackburn, J.P. Flatt, J. Sizer, N.S. Scrimshaw, M. Sherman, Nitrogen metabolism and insulin requirements in obese diabetic adults on a protein-sparing modified fast. Diabetes 25(6), 494-504 (1976)

15. B.R. Bistrian, Clinical use of a protein-sparing modified fast. JAMA 240(21), 2299-2302 (1978)

16. A. Palgi, J.L. Read, I. Greenberg, M.A. Hoefer, B.R. Bistrian, G.L. Blackburn, Multidisciplinary treatment of obesity with a proteinsparing modified fast: results in 688 outpatients. Am. J. Public Health 75(10), 1190-1194 (1985)

17. J.K. Walters, B.J. Hoogwerf, S.S. Reddy, The protein-sparing modified fast for obesity-related medical problems. Cleve Clin. J. Med. 64(5), 242-244 (1997)

18. N.B. Bueno, I.S. de Melo, S.L. de Oliveira, T. da Rocha Ataide, Very-low-carbohydrate ketogenic diet v. low-fat diet for longterm weight loss: a meta-analysis of randomised controlled trials. Br. J. Nutr. 110(7), 1178-1187 (2013). https://doi.org/10.1017/ S0007114513000548

19. M. Castellana, E. Conte, A. Cignarelli, S. Perrini, A. Giustina, L. Giovanella, F. Giorgino, P. Trimboli, Efficacy and safety of very low calorie ketogenic diet (VLCKD) in patients with overweight and obesity: a systematic review and meta-analysis. Rev. Endocr. Metab. Disord. 21(1), 5-16 (2020). https://doi.org/10.1007/ s11154-019-09514-y

20. A. Pfützner, T. Kunt, C. Hohberg, A. Mondok, S. Pahler, T. Konrad, G. Lübben, T. Forst, Fasting intact proinsulin is a highly specific predictor of insulin resistance in type 2 diabetes. Diabetes Care 27(3), 682-687 (2004)

21. C. von Berghes, G. Brabant, H. Biebermann, H. Krude, S. Wiegand, Proinsulin and the proinsulin/insulin ratio in overweight and obese children and adolescents: relation to clinical parameters, insulin resistance, and impaired glucose regulation. Pediatr. Diabetes 12(3 Pt 2), 242-249 (2011). https://doi.org/10.1111/j.13995448.2010.00734.x

22. A.M. El Shabrawy, K.A. Elbana, N.M. Abdelsalam, Proinsulin/ insulin ratio as a predictor of insulin resistance and B-cell dysfunction in obese Egyptians (insulin resistance \& B-cell dysfunction in obese Egyptians). Diabetes Metab. Syndr. 13(3), 2094-2096 (2019). https://doi.org/10.1016/j.dsx.2019.04.044
23. F.A.F. El-Messallamy, H.M. El-Ashmawy, A.M. El Shabrawy, S. E. Radwan, Proinsulin/insulin ratio as a predictor of insulin resistance in patients with diabetic nephropathy. Diabetes Metab. Syndr. 13(3), 2057-2060 (2019). https://doi.org/10.1016/j.dsx. 2019.04.036

24. C. von Berghes, G. Brabant, H. Biebermann, H. Krude, S. Wiegand, Proinsulin and the proinsulin/insulin ratio in overweight and obese children and adolescents: relation to clinical parameters, insulin resistance, and impaired glucose regulation. Pediatr. Diabetes 12(3 Pt 2), 242-249 (2011). https://doi.org/10.1111/j.13995448.2010.00734.x

25. S. Bhasin, J.P. Brito, G.R. Cunningham, F.J. Hayes, H.N. Hodis, A.M. Matsumoto, P.J. Snyder, R.S. Swerdloff, F.C. Wu, M.A. Yialamas, Testosterone therapy in men with hypogonadism: an endocrine society clinical practice guideline. J. Clin. Endocrinol. Metab. 103(5), 1715-44. (2018)

26. A. Engin, The definition and prevalence of obesity and metabolic syndrome. Adv. Exp. Med. Biol. 960, 1-17 (2017). https://doi. org/10.1007/978-3-319-48382-5_1

27. G. Nijpels, C. Popp-Snijders, P.J. Kostense, L.M. Bouter, R.J. Heine, Fasting proinsulin and 2-h post-load glucose levels predict the conversion to NIDDM in subjects with impaired glucose tolerance: the Hoorn Study. Diabetologia 39(1), 113-118 (1996). https://doi.org/10.1007/BF00400421

28. J.A. Galloway, S.A. Hooper, C.T. Spradlin, D.C. Howey, B.H. Frank, R.R. Bowsher, J.H. Anderson, Biosynthetic human proinsulin. Review of chemistry, in vitro and in vivo receptor binding, animal and human pharmacology studies, and clinical trial experience. Diabetes Care 15(5), 666-692 (1992). https://doi. org/10.2337/diacare.15.5.666

29. R.J. Katz, R.E. Ratner, R.M. Cohen, E. Eisenhower, D. Verme, Are insulin and proinsulin independent risk markers for premature coronary artery disease? Diabetes 45(6), 736-741 (1996). https:// doi.org/10.2337/diab.45.6.736

30. P. Båvenholm, A. Proudler, P. Tornvall, I. Godsland, C. Landou, U. de Faire, A. Hamsten, Insulin, intact and split proinsulin, and coronary artery disease in young men. Circulation 92(6), 1422-1429 (1995). https://doi.org/10.1161/01.cir.92.6.1422

31. J.S. Yudkin, A.E. Denver, V. Mohamed-Ali, K.L. Ramaiya, D.K. Nagi, S. Goubet, D.G. McLarty, A. Swai, The relationship of concentrations of insulin and proinsulin-like molecules with coronary heart disease prevalence and incidence. A study of two ethnic groups. Diabetes Care 20(7), 1093-1100 (1997). https:// doi.org/10.2337/diacare.20.7.1093

32. A. Pfützner, A.H. Pfützner, M. Larbig, T. Forst, Role of intact proinsulin in diagnosis and treatment of type 2 diabetes mellitus. Diabetes Technol. Ther. 6(3), 405-412 (2004). https://doi.org/10. 1089/152091504774198124

33. A. Pfützner, P.H. Kann, A.H. Pfützner, T. Kunt, M. Larbig, M.M. Weber, T. Forst, Intact and total proinsulin: new aspects for diagnosis and treatment of type 2 diabetes mellitus and insulin resistance. Clin. Lab. 50(9-10), 567-573 (2004)

34. B. Zethelius, L. Byberg, C.N. Hales, H. Lithell, C. Berne, Proinsulin and acute insulin response independently predict Type 2 diabetes mellitus in men-report from 27 years of follow-up study. Diabetologia 46(1), 20-26 (2003). https://doi.org/10.1007/ s00125-002-0995-2

35. J. Bolinder, P. Fernlund, H. Borg, H.J. Arnqvist, E. Björk, G. Blohmé, J.W. Eriksson, L. Nyström, J. Ostman, G. Sundkvist, Hyperproinsulinemia segregates young adult patients with newly diagnosed autoimmune (type 1) and non-autoimmune (type 2) diabetes. Scand. J. Clin. Lab. Investig. 65(7), 585-594 (2005). https://doi.org/10.1080/00365510500261869

36. J. Vangipurapu, A. Stančáková, T. Kuulasmaa, J. Kuusisto, M. Laakso, Both fasting and glucose-stimulated proinsulin levels predict hyperglycemia and incident type 2 diabetes: a population- 
based study of 9,396 Finnish men. PLoS ONE 10(4), e0124028 (2015). https://doi.org/10.1371/journal.pone.0124028

37. T. Ohkura, K. Inoue, Y. Fujioka, R. Nakanishi, H. Shiochi, K. Sumi, N. Yamamoto, K. Matsuzawa, S. Izawa, H. Ohkura, M. Kato, K. Yamamoto, S. Taniguchi, The proinsulin/insulin (PI/I) ratio is reduced by postprandial targeting therapy in type 2 diabetes mellitus: a small-scale clinical study. BMC Res. Notes 6 , 453 (2013). https://doi.org/10.1186/1756-0500-6-453

38. F. Capstick, B.A. Brooks, C.M. Burns, R.R. Zilkens, K.S. Steinbeck, D.K. Yue, Very low calorie diet (VLCD): a useful alternative in the treatment of the obese NIDDM patient. Diabetes Res Clin. Pr. 36(2), 105-111 (1997). https://doi.org/10.1016/ s0168-8227(97)00038-7

39. A.E. Rothberg, L.N. McEwen, A.T. Kraftson, C.E. Fowler, W.H. Herman, Very-low-energy diet for type 2 diabetes: an underutilized therapy? J. Diabetes Complic. 28(4), 506-510 (2014). https://doi.org/10.1016/j.jdiacomp.2014.03.014

40. S. Steven, K.G. Hollingsworth, A. Al-Mrabeh, L. Avery, B. Aribisala, M. Caslake, R. Taylor, Very Low-Calorie Diet and 6 Months of Weight Stability in Type 2 diabetes: pathophysiological changes in responders and nonresponders. Diabetes Care 39 (5), 808-815 (2016). https://doi.org/10.2337/dc15-1942

41. A. Goday, D. Bellido, I. Sajoux, A.B. Crujeiras, B. Burguera, P.P. García-Luna, A. Oleaga, B. Moreno, F.F. Casanueva, Short-term safety, tolerability and efficacy of a very low-calorie-ketogenic diet interventional weight loss program versus hypocaloric diet in patients with type 2 diabetes mellitus. Nutr. Diabetes 6(9), e230 (2016). https://doi.org/10.1038/nutd.2016.36

42. I. Partsalaki, A. Karvela, B.E. Spiliotis, Metabolic impact of a ketogenic diet compared to a hypocaloric diet in obese children and adolescents. J. Pediatr. Endocrinol. Metab. 25(7-8), 697-704 (2012). https://doi.org/10.1515/jpem-2012-0131

43. Y. Gu, H. Yu, Y. Li, X. Ma, J. Lu, W. Yu, Y. Xiao, Y. Bao, W. Jia, Beneficial effects of an 8-week, very low carbohydrate diet intervention on obese subjects. Evid. Based Complement Altern. Med. 2013, 760804 (2013). https://doi.org/10.1155/2013/760804.

44. P.F. Svendsen, F.K. Jensen, J.J. Holst, S.B. Haugaard, L. Nilas, S. Madsbad, The effect of a very low calorie diet on insulin sensitivity, beta cell function, insulin clearance, incretin hormone secretion, androgen levels and body composition in obese young women. Scand. J. Clin. Lab. Investig. 72(5), 410-419 (2012). https://doi.org/10.3109/00365513.2012.691542

45. I. P. Doulamis, A. Tzani, P. Konstantopoulos, A. Daskalopoulou, T. Spinos, E. Bletsa, D. Mitsopoulou, M. Spinou, M. E. Brinia, K.
Palaiopanos, L. M. Korou, D. N. Perrea, N. L. Katsilambros, Experimental hypogonadism: insulin resistance, biochemical changes and effect of testosterone substitution. J. Basic Clin. Physiol. Pharmacol. 2019; 30(3). https://doi.org/10.1515/jbcpp2018-0118

46. D.M. Kelly, T.H. Jones, Testosterone: a metabolic hormone in health and disease. J. Endocrinol. 217(3), R25-R45 (2013). https://doi.org/10.1530/JOE-12-0455

47. L.T. van Hulsteijn, R. Pasquali, F. Casanueva, S. Haluzik Ledoux, M.P. Monteiro, J. Salvador, F. Santini, H. Toplak, O.M. Dekkers, Prevalence of endocrine disorders in obese patients: systematic review and meta-analysis. Eur. J. Endocrinol. 182(1), 11-21 (2020). https://doi.org/10.1530/EJE-19-0666

48. G. Corona, G. Rastrelli, G. Di Pasquale, A. Sforza, E. Mannucci, M. Maggi, Endogenous testosterone levels and cardiovascular risk: meta-analysis of observational studies. J. Sex. Med. 15(9), 1260-1271 (2018). https://doi.org/10.1016/j.jsxm.2018.06.012

49. J. Kaukua, T. Pekkarinen, T. Sane, P. Mustajoki, Sex hormones and sexual function in obese men losing weight. Obes. Res. 11(6), 689-694 (2003). https://doi.org/10.1038/oby.2003.98

50. L. Niskanen, D.E. Laaksonen, K. Punnonen, P. Mustajoki, J. Kaukua, A. Rissanen, Changes in sex hormone-binding globulin and testosterone during weight loss and weight maintenance in abdominally obese men with the metabolic syndrome. Diabetes Obes. Metab. 6(3), 208-215 (2004). https://doi.org/10.1111/j.1462-8902.2004.00335.x

51. M. Ng Tang Fui, L.A. Prendergast, P. Dupuis, M. Raval, B.J. Strauss, J.D. Zajac, M. Grossmann, Effects of testosterone treatment on body fat and lean mass in obese men on a hypocaloric diet: a randomised controlled trial. BMC Med. 14(1), 153 (2016). https://doi.org/10.1186/s12916-016-0700-9

52. V.A. Giagulli, M. Castellana, M.D. Carbone et al. Weight loss more than glycemic control may improve testosterone in obese type 2 diabetes mellitus men with hypogonadism. Andrology 8(3), 654-662 (2020). https://doi.org/10.1111/andr.12754

53. C. Pelusi, V.A. Giagulli, M. Baccini et al. Clomiphene citrate effect in obese men with low serum testosterone treated with metformin due to dysmetabolic disorders: a randomized, doubleblind, placebo-controlled study. PLoS ONE 12(9), e0183369 (2017). https://doi.org/10.1371/journal.pone.0183369

54. R. Cannarella, R.A. Condorelli, L.M. Mongiò̀, F. Barbagallo, A. E. Calogero, La, S. Vignera, Effects of the selective estrogen receptor modulators for the treatment of male infertility: a systematic review and meta-analysis. Expert Opin. Pharmacother. 20 (12), 1517-1525 (2019) 